\title{
Is a persistent adenovirus infection involved in coeliac disease?
}

\author{
M J CARTER, M M WILLCOCKS, H C MITCHISON, C O RECORD, \\ AND C R MADELEY \\ From the Department of Virology, The University of Newcastle-upon-Tyne, New Medical School and \\ Gastroenterology Unit, Royal Victoria Infirmary and Newcastle University, Newcastle-upon-Tyne
}

SUMmARY Recent evidence has implicated adenovirus 12 in the aetiology of coeliac disease so that persistent infection by this virus must be considered. We have undertaken a search for adenovirus DNA in duodenal biopsy samples from a total of 26 coeliac and non-coeliac patients. We could find no evidence of persistent virus DNA by Southern blot techniques even under conditions which approach a sensitivity of one copy of virus genome per cell, and use either adenovirus 12 or 41 DNA.

Coeliac disease is characterised by the inability of the gut to process wheat proteins correctly. In particular, the gliadin fraction of the wheat protein gluten activates an immune response which leads to damage of the small intestinal mucosa and malabsorption of the products of digestion.'

The aetiology of coeliac disease remains unclear, but attention has recently focused on a possible role for adenoviruses, which cause common, often symptomless, infections of the gut. In a recent examination of protein sequence and immunological cross-reactivity, Kagnoff $e t a l^{3}$ reported a striking similarity between gliadin and an early protein, E1b, synthesised by adenovirus type 12, subsequently showing a significant rise of adenovirus 12-specific neutralising antibody in treated and non-treated coeliac disease patients compared with the population at large. These patients had no significantly increased antibody titres to related adenoviruses, or to other gut viruses. ${ }^{+}$

Adenovirus 12 is one of the less common adenoviruses, accounting for only $1.68 \%$ of enteric adenovirus diagnoses in Newcastle-upon-Tyne over the last two years. ${ }^{5}$ These infections are still much more common than coeliac disease, however, and it is clear that this virus cannot be the sole cause and a host dependent function may be involved. Adenoviruses are well known to establish persistent infections in tissue culture, and persistence in the gut

Address for correspondence: Dr M J Carter. Dept of Virology. The Medical School, Framlington Place. Newcastle upon Tyne NE2 4HH.

Accepted for publication 21 March 1989. associated with prolonged faecal shedding of virus has also been reported. ${ }^{\circ}$ In tissue culture, adenovirus persistence is associated with the maintenance of virus early genes leading to cell transformation and uncontrolled cell growth.' It is also known that coeliac patients have an increased risk of malignant neoplasms; in particular of small-intestinal lymphomas and adenocarcinomas. ${ }^{8}$ These observations led us to the hypothesis that one of the processes involved in the possible adenoviral aetiology of coeliac disease might be the establishment of a persistent infection by the virus in gut tissue, most likely in the small intestine.

We therefore undertook a search of persistent adenovirus DNA in duodenal biopsy samples from coeliac and non-coeliac patients, using radiolabelled adenovirus DNA probes. Samples could not be obtained from fully normal individuals for ethical reasons and post mortem tissue was therefore obtained as a negative control.

\section{Methods}

PATIENTS AND SAMPLES

Biopsies were obtained from 26 patients after intravenous sedation. Samples were collected from the second or third part of the duodenum using (in adults) a large $(3.7 \mathrm{~mm})$ channel endoscope. In 13 patients there was a diagnosis of coeliac disease (12 women, mean age 45 years, range 21-71). In 11 the diagnosis had been made a minimum of two years before and they were believed to be compliant with a 
gluten free diet. Routine histology showed no significant abnormality in five, partial villous atrophy in five and total villous atrophy in one. In the other two patients the diagnosis was new and the biopsies showed subtotal or total villous atrophy. In 13 patients coeliac disease was not diagnosed. Two were infants and biopsies were done to exclude coeliac disease because of failure to thrive (ultimately thought not to be organic in origin). In both cases minimal changes in villous structure were found but were not thought to amount to the changes of untreated coeliac disease and in one a trial of gluten free diet was ineffective. In the remaining 11 (10 women, mean age 46 years, range 23-73), biopsies were taken to exclude coeliac disease as a cause of anaemia and/or diarrhoea (10), or to investigate the cause of dyspepsia (one).

TISSUE PROCESSING

Samples from endoscopy were stored at $-70^{\circ} \mathrm{C}$ until processed. Processing was performed by grinding the thawed sample on ice in SDS buffer $(10 \mathrm{mM} \mathrm{Tris- \textrm {HCl }}$ $\mathrm{pH} 7 \cdot 4,5 \mathrm{mM}$ EDTA, 0.5\% SDS) using a glass homogeniser. Proteinase $\mathrm{K}$ was then added to a final concentration of $10 \mu \mathrm{g} / \mathrm{ml}$ and the sample was incubated at $37^{\circ} \mathrm{C}$ for one hour. Total nucleic acid was extracted with NTE $(100 \mathrm{mM} \mathrm{NaCl}, 10 \mathrm{mM}$ Tris- $\mathrm{HCl} \mathrm{pH} \mathrm{7.4,} 1 \mathrm{mM}$ EDTA)-saturated phenol containing $0 \cdot 1 \%$-hydroxy quinoline, and precipitated with ethanol. Samples were redissolved, reprecipitated from $2 \mathrm{M}$ ammonium acetate and finally resuspended in water. A typical sample of $20 \mathrm{mg}$ yielded approximately $70 \mu \mathrm{g}$ nucleic acid.

ELECTROPHORESIS AND BLOTTING ANALYSIS The restriction digest patterns of most types of adenovirus DNA are now known." The enzyme EcoR1 has been found useful in the identification of adenovirus serotypes by this method and as persistent DNA may be in an integrated form, it was decided to use this enzyme for digestion of the samples. Accordingly, nucleic acid was adjusted to $1 \times E c o \mathrm{R} 1$ buffer $(0 \cdot 1 \mathrm{M}$ Tris- $\mathrm{HCl} \mathrm{pH} 7 \cdot 5,50 \mathrm{mM}$ $\mathrm{NaCl}, 6 \mathrm{mM} \mathrm{MgCl}$, 6 mM 2-mercaptoethanol) using the $10 \times$ concentrate supplied with the enzyme. Ten units of EcoR1 (Northumbria Biologicals Ltd, Cramlington, Northumberland) were then added and the sample incubated at $37^{\circ} \mathrm{C}$ for 60 minutes. At the end of this time an equal volume of sample buffer (10\% glycerol, $2 \times$ TBE, $0 \cdot 01 \%$ bromophenol blue) was added and the restriction fragments separated by electrophoresis through a $1 \cdot 2 \%$ agarose gel in $1 \times$ TBE running buffer $(0.089 \mathrm{M}$ Tris-borate, $0.089 \mathrm{M}$ boric acid, 0.002 M EDTA pH 8.0) containing $0.5 \mu \mathrm{g} / \mathrm{ml}$ ethidium bromide. DNA size markers were also loaded onto these gels to give bands at:
$21 \cdot 7,5 \cdot 15,5 \cdot 0,4 \cdot 27,3 \cdot 48,1 \cdot 98,1 \cdot 9,1 \cdot 59,1 \cdot 37,0 \cdot 94$, and 0.83 kilobasepairs (kbp). After electrophoresis the gel was photographed under ultraviolet light before DNA was transferred to nitrocellulose filters. The gel was first soaked in $1.5 \mathrm{M} \mathrm{NaCl},() \cdot 5 \mathrm{M} \mathrm{NaOH}$ for one hour to denature the nucleic acid, and then

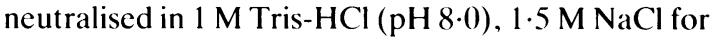
a further hour. Transfer to a filter was performed in $20 \times \mathrm{SSC}$ transfer buffer ( $3 \mathrm{M} \mathrm{NaCl}, 0 \cdot 3 \mathrm{M}$ sodium citrate) using a Hybaid vacuum blotting apparatus. The filters were baked at $80^{\circ} \mathrm{C}$ for two hours and stored dry at $4^{\circ} \mathrm{C}$ before hybridisation.

PREPARATION OFRADIOLABELLED DNA PROBES Two types of adenovirus DNA were used. Adenovirus 12 was grown in $\mathrm{KB}$ cells, kindly provided by $\mathrm{Dr}$ $\mathrm{V}$ Mautner, Institute of Virology, University of Glasgow. Infected cells were harvested when the cytopathic effect was extensive and virus DNA was prepared from them by the method of Brown, Petric, and Middleton." The resultant DNA was digested with EcoRl and separated on a $1 \cdot 2 \%$, agarose gel as described above. Under these conditions band $\mathrm{C}$, which corresponds to the left hand end of the genome and contains those sequences expected to be conserved in persistent infection, was clearly separated. This segment of the genome contains all of the Ela region, and most of the Elb gene." The area of the gel containing this band was excised, and the DNA electroeluted into a dialysis sac for recovery by phenol extraction and ethanol precipitation.

A second adenovirus was also used. Adenovirus 41 is the most commonly identified enteric adenovirus in the Newcastle area, 5 and has recently been cloned in our laboratory (manuscript in preparation). The left hand end of the genome from this virus also contains the early region genes and a $2 \cdot 6 \mathrm{~kb} E c o \mathrm{R} 1$ restriction fragment is known to be derived from this area. ${ }^{12}$ This fragment has been cloned into the Pst-1 site of the vector pBR322, from which it can be recovered in pure form by $P$ st-1 digestion and electroelution in a similar manner to that described above. Purified DNA fragments from both viruses (10 ng) were radiolabelled using high specific activity "2P-dCTP $3000 \mathrm{Ci} / \mathrm{mmol}$ (Amersham International plc) in the random hexanucleotide priming method of Feinberg and Vogelstein. ${ }^{13}$ The specific activities of probes prepared in this way were in excess of $2 \times 10^{\prime \prime} \mathrm{cpm} / \mu \mathrm{g}$. The filters to which the DNA fragments had been transferred were hybridised under standard conditions. ${ }^{14}$ Any excess capacity for binding DNA was blocked by prehybridising the filter at $65^{\circ} \mathrm{C}$ in $6 \times \mathrm{SSC}$ containing $0.5 \%$ SDS, $100 \mu \mathrm{g} / \mathrm{ml}$ denatured calf thymus DNA and $5 \times$ Denhardt's solution ( $) \cdot 1 \%$ each Ficoll, polyvinylpyrollidone, bovine serum albumin). Hybridisation proper was performed for 18 hours at 


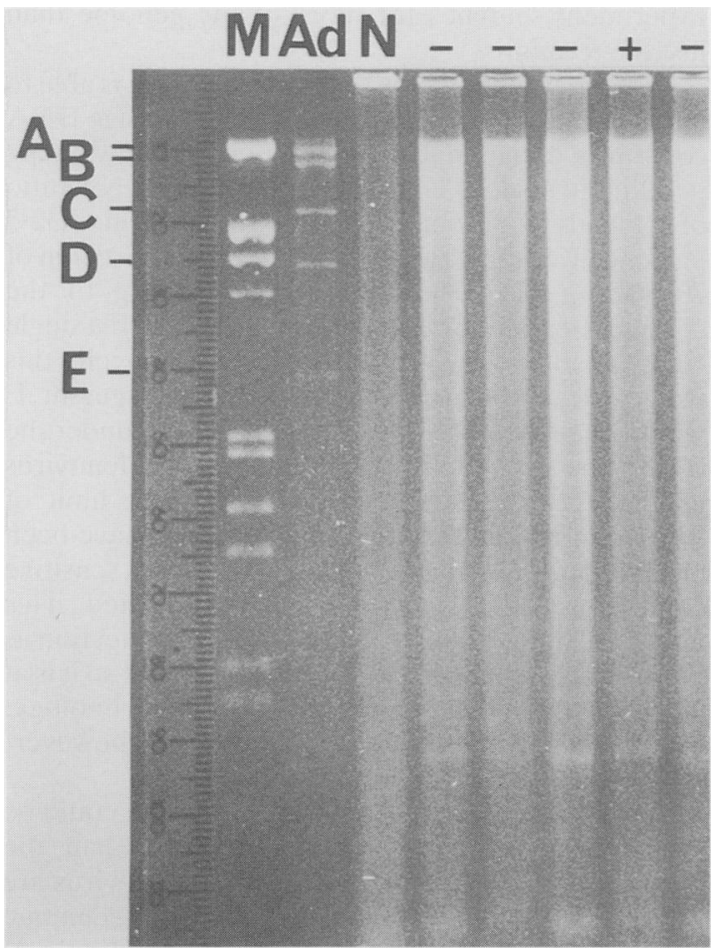

Fig. 1 Typical analysis of DNA extracted from adenovirus infected $K B$ cells and duodenum tissue samples. DNA was extracted as described, digested with the restriction enzyme ECoRI electrophoresed through a $1 \cdot 2 \%$ agarose gel and stained with ethidium bromide. Photograph taken under ultraviolet light. M: DNA size markers (Phage Lambda $D N A$ digested with enzymes $\mathrm{ECoR} 1$ and $\mathrm{Hind}(I I)$, Ad: adenovirus 12 DNA from infected cells (virus DNA bands $A$ to $E$ are indicated), $\mathrm{N}$ : normal tissue obtained post-mortem from an individual with no history of coeliac disease. All tracks marked + or - are duodenum biopsy samples, +: samples from patients diagnosed as coeliac, - : samples from non-coeliac patients.

$65^{\circ} \mathrm{C}$ in the same buffer adjusted to $0 \cdot 1 \mathrm{M}$ with EDTA and $10^{\circ} \mathrm{cpm} / \mathrm{ml}$ probe DNA. After hybridisation filters were washed three times for one hour each at room temperature using $2 \times \mathrm{SSC}, 0 \cdot 1 \%$ SDS, and two times for one hour each using $0 \cdot 1 \times \mathrm{SSC}, 0 \cdot 1 \% \mathrm{SDS}$ at $65^{\circ} \mathrm{C}$. The washed filters were sandwiched wet between two sheets of cling film and exposed to Fuji $x$-ray film at $-70^{\circ} \mathrm{C}$ using intensifier screens for periods of up to two weeks.

\section{Results}

Twenty six samples of duodenal DNA were examined under code. One quarter of each sample was used for each analysis. Figure 1 shows the

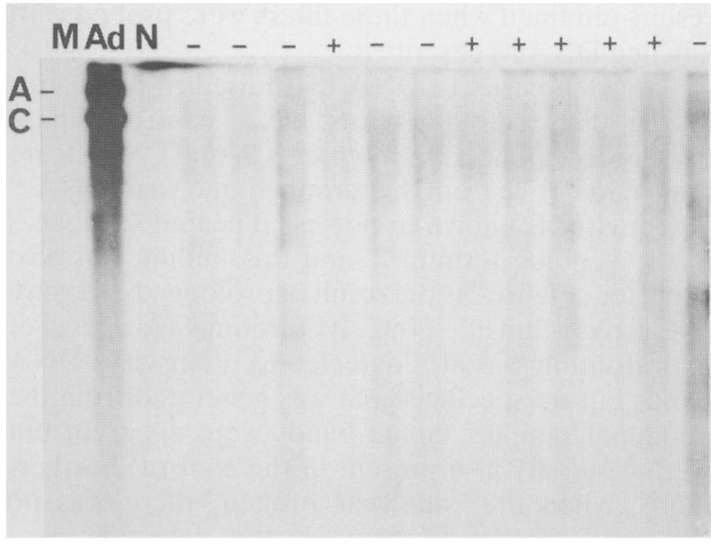

Fig. 2 Gel as in Figure 1, blotted onto nitrocellulose filter and hybridised to radiolabelled adenovirus $12 \mathrm{DNA}$, fragment $C$, and autoradiographed. Ad: control adenovirus $12 D N A, \mathrm{~N}$ : normal duodenum DNA, +: DNA from coeliac patient duodenum biopsy, -: DNA from non-coeliac patient duodenum biopsy. Hybridising virus DNA fragments $A$ and $C$ are indicated.

appearance of a typical ethidium bromide stained gel under ultraviolet light. All samples gave rise to a smear of DNA in which few specific bands could be resolved. This pattern is expected after the digestion of high molecular weight DNA from the eukaryotic genome. Virus DNA digested under the same conditions produced a clear pattern characteristic of adenovirus 12. Five DNA bands termed A-E were clearly visible and are indicated in the figure. The remaining fragment $(\mathrm{F})$ was too faint to be photographed. Figures 2 and 3 present representative

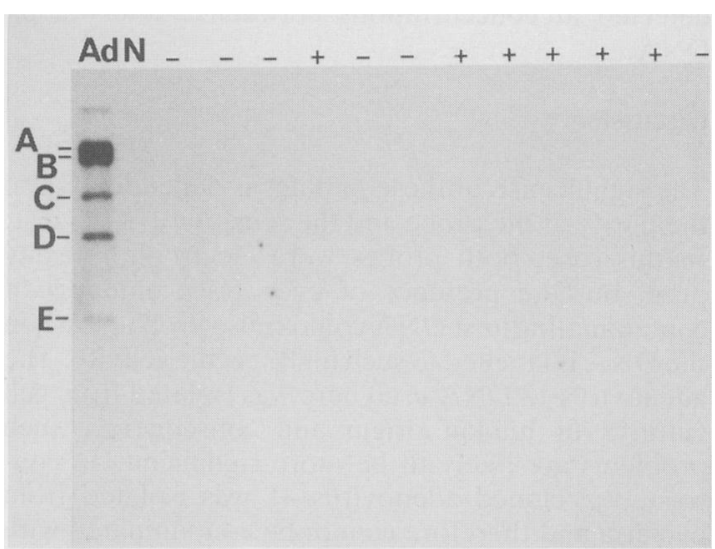

Fig. 3 Replicate gel as in Figure 2, blotted and hybridised to radiolabelled cloned adenovirus 41 DNA (ECoR1 fragment E) containing the early region of the virus genome. Symbols as in Figure 2. Hybridising adenovirus 12 DNA fragments $A$ to E are indicated. 
results obtained when these filters were probed with labelled DNA as described.

The adenovirus 12 DNA hybridised to two bands in the digested adenovirus DNA control. These bands corresponded to fragments $\mathrm{A}$ and $\mathrm{C}$ which are known to derive from the termini of the virus DNA." Adenovirus is known to possess repeated sequences at the genome termini ${ }^{15}$ th and this finding was also expected. Figure 2 is the result of prolonged exposure of the $x$-ray film at $-70^{\circ} \mathrm{C}$. At this time a low level of hydridisation was also detected to other virus DNA bands but no specific signal was generated from the duodenal samples. Some bands were apparent but were generally also present in the control. Furthermore, when the code was broken, there was no apparent correlation between the detection of a DNA band and the diagnosis of coeliac disease.

Figure 3 presents the results of the same analysis performed using the adenovirus 41 cloned DNA. The result is generally clearer and specific hybridisation was only observed in the track containing adenovirus 12 DNA. Faint but discrete bands were just visible on the film but once more their presence failed to correlate with the clinical diagnosis of coeliac disease. Interestingly, the genome terminus of adenovirus 41 contains sequences that are contained in the internal regions of adenovirus 12 DNA and the probe recognised all the internal restriction fragments of this virus DNA as well as the terminal regions.

The sensitivity of the test was investigated by probing serial dilutions of adenovirus 41 DNA fragment $E$ made in calf thymus DNA and subjected to electrophoresis and transfer as described. Under these conditions the signal could no longer be detected at concentrations between 2 and $0.2 \mathrm{pg}$ DNA.

\section{Discussion}

The significance of these findings is dependent upon the purity of the probe and the sensitivity of the test. In this case, both probes were electrophoretically pure, but the presence of even trace amounts of contaminating host DNA could cause problems when the DNA is labelled to such high specific activity. The adenovirus 12 DNA used here was isolated from cell cultures of human origin and consequently such problems are likely to be more significant. In contrast, the cloned adenovirus 41 was isolated from bacteria and therefore cannot be contaminated with any human DNA whatsoever. This is probably the reason for the differences between the results generated by the two analyses. The adenovirus 41 probe recognised all fragments deriving from adenovirus 12 under these conditions and consequently this experiment searches for more of the genome than just the termini.

Our experiments show that this technique is able to detect as little as $2 \mathrm{pg}$ virus DNA. The average DNA content of a mammalian cell is approximatcly $6.6 \mathrm{pg}$ per diploid nucleus, and an average RNA:DNA ratio of $4: 1$ leads to an average nucleic acid content of 32.5 pg per cell. Samples generally yielded in the region of $70-100 \mu \mathrm{g}$ of nucleic acid corresponding to the contents of approximately $2-3$ million cells. If a single copy of adenovirus DNA is present per cell, this would mean that $6-10 \mathrm{pg}$ adenovirus fragment $\mathrm{E}$ would be present in such a sample. Hence, under the conditions used here one copy of the adenovirus genome per cell would have been at the limit of detection, and any higher content should have been clearly demonstrated. Even under these sensitive conditions no virus DNA could be detected. This analysis cannot exclude a persistent virus infection as part of the actiology of coeliac discase, but if so it is at a level too low to be detected by this technology. Polymerase chain reaction techniques, however, could increase the sensitivity.

An alternative explanation of this finding could be that the virus persists elsewhere other than the duodenal mucosa, the cells harbouring the virus are not therefore sampled by the endoscopic technique used. Cells from malignant transformations of coeliac small intestine should be investigated as they would constitute a homogeneous population of transformed cells - that is, those cells most likely to contain the virus DNA.

\section{References}

1 Kasarda DD. Toxic proteins and peptides in celiac disease: relation to cereal genetics. In: Walcher D, Kretchmar M, eds. Food, nutrition and evolution. New York: Masson, 1981: 201-16.

2 Falchuk ZM. Update on gluten-sensitive enteropathy. Am J Med 1979; 67: 1085-96.

3 Kagnoff MF, Austin RY, Hubert JJ, Beradin JE, Kasarda DD. Possible role for a human adenovirus in the pathogenesis of celiac discase. J Exp Med 1984; 160: $1544-57$.

4 Kagnoff MF, Paterson YJ, Kumar PJ, et al. Evidence for the role of a human intestinal adenovirus in the pathogenesis of coeliac discase. Gut 1987; 28: 995-1001.

5 Willcocks MM, Carter MJ, Laidler F. Madeley CR. Restriction enzyme analysis of faccal adenoviruses in Newcastle-upon-Tyne. Epidemiol Infect 1988; 101: 44.558.

6 Kidd AH, Cosgrove BP. Brown RA. Madeley CR. Faccal adenoviruses from Glasgow babies: studies on culture and identity. J Hyg Camb 1982; 88: 46.3-74.

7 Graham FL, Abrahams PJ. Mulder C. et al. Studies on in vitro transformation by DNA and DNA fragments of human adenoviruses and simian virus 40. Cold Spring Harbor Symp Quant Biol 1974: 39: 6.37-50. 
8 Swinson CM, Slavin G, Coles EC, Booth CC. Coeliac disease and malignancy. Lancet 1983; i: 111-5.

9 Wadell G. Adenoviruses. In: Zuckerman AJ, Banatvala JE, Pattison JR, eds. Principles and practice of clinical virology. New York: Wiley, 1988: 251-74.

10 Brown M. Petric M, Middleton PJ. Silver staining of DNA restriction fragments for the rapid identification of adenovirus isolates: Application during nosocomial outbrcaks. J Virol Methods 1984; 9: 87-98.

11 Jochemsen H, Daniels GSG, Lupker JH, Van der Eb AJ. Identification and mapping of the early gene products of adenovirus type 12. Virology 1980; 105: 55163.

12 Takiff HE, Reinhold W, Garon GF, Strauss SE.
Cloning and physical mapping of enteric adenoviruses (candidate types 40 and 41). J Virol 1984; 51: 131-6.

13 Feinberg AP, Vogelstein B. A technique for radiolabelling DNA restriction endonuclease fragments to high specific activity. Anal Biochem 1984; 137: 266-7.

14 Maniatis T. Fritsch EF. Sambrook J. Molecular cloning. A laboratory manual. Cold Spring Harbour Laboratory USA, 1982.

15 Wolfson J, Dressler D. Adenovirus 2 DNA contains an inverted terminal repetition. Proc Natl Acad Sci USA 1972; 69: 3054-7.

16 Garon CF, Berry KW, Rose JA. An unique form of terminal redundancy in adenovirus DNA molecules. Proc Natl Acad Sci USA 1972; 69: 2391-5. 